\title{
The Determining Factors of Student Intention to Donate in Social Crowdfunding Media
}

\author{
Cynthia Ayu Manggarani, ${ }^{\mathrm{a} *}$, Zulfikar Ali Ahmad \\ ${ }^{a}$ STIE YKPN, Yogyakarta, Indonesia
}

\begin{abstract}
The issue of social crowdfunding has been widely discussed in various countries. In Indonesia, social crowdfunding media platforms are frequently used for social activities such as the donation for the victims of natural disasters or donation for people who suffer from a financial deficiency. However, empirical research on social crowdfunding is finite. Even though the platform has been extensively used by society, the lack of interest towards study in social crowdfunding is evident due to the obscureness of government regulations regarding the fundraising media. Considering the enormous contribution of social crowdfunding media for the people in need, the enthusiasm of the society to participate in the donation activities thus need to be elevated. This study aims to determine the degree of one's motivation in trying to try to donate through social crowdfunding media. The data of this research was collected using a survey method with a total of 300 respondents.
\end{abstract}

\section{Keywords:}

theory of trying, attitude, intention, social crowdfunding

\section{INTRODUCTION}

Exquisitely, every higher educational institution across the world has a moral obligation to provide benefits to society. Not only the service can be done by the member of the institution, but also it can be done by the students who want to contribute to the activity that can be beneficial for society. In Indonesia, there is Tri Dharma Perguruan Tinggi, which is the principal of every higher educational institution in Indonesia to conduct three activities which include teaching, researching, and providing service to the society. To accomplish the third point, it is common for universities to conduct community service programs to trigger student's motivation in helping others. So that the core mission of formal education is not simply to ensure that students are being taught but also to ensure that they learn.

Considering the fact that based on the data of World Bank, out of Indonesia's population of around 260 million, approximately 25.9 million Indonesians still live below the poverty line. In 2017, the income of around $20.78 \%$ of the entire population is floating above the national poverty line (World Bank, 2019). Although there are improvements in the country's public services (Nuswantoro, 2019), the quality of health clinics

\footnotetext{
* Author in correspondence,

Email address: cynthia.mrsc@gmail.com (Cynthia Ayu Manggarani ), zulfikar.ali.ahmad15@gmail.com (Zulfikar Ali Ahmad)
}

ISSN: 2549-3221 (Print) 2549-323X (Online)

DOI: $10.26487 /$ hebr.v4i1.2294
(Indonesia Investments, 2019) and education are still impoverished (World Education News +Reviews, 2019). While around 9 million children in Indonesia suffer from stunting which reflects abnormal brain development (Simorangkir, 2018).

The data shows that a lot of people are in need to be helped. Thus, it is the role of any higher educational institution to act as a motivational driver for its scholars to do particular action for the welfare of society through education. Although actually, the success and popularity of charity activity itself is not uncommon in Indonesia (e.g., Cosgrave (2007)); Charities Aid Foundation 2013). In Indonesia, there was an existing phenomenon of students helping others in Indonesia. They gather in the street to collect money to help people in need. However, the country's government has prohibited such actions. Hence, there should be an alternative for people who want to help others in need.

A fundraising activity through social crowdfunding media is becoming a public concern because of its success in funding many social projects (Bernardino et al., 2016). The increase in the number of social crowdfunding enthusiasts is shown by the immense devotion of people in developed countries such as America, to donate through social crowdfunding media (Fintech Singapore, 2019). The donation using this platform is perceived as easier and less time-consuming.

Youth and university students have been becoming alluring objects for most researchers when conducting their studies (Sara et al., 2018). Student's courage to try new things, especially in terms of technology, making them appealing for any stakeholder who wants to offer their products via online media. 
Several studies show that students are most likely to engage in altruistic behavior (e.g., Coulter et al. (2007); Buragohain and Sonowal (2016), Guo et al. (2017). However, in relation to student donation behavior, several studies showed that the empirical studies of student behavior to donate money were rare compared to organ or blood donation.

In contrast to equity crowdfunding which is intended for the acquisition of personal benefits for its investors, social crowdfunding's main goal is aimed to help people who need funds. While for investors, social crowdfunding may provide to fulfill their emotional needs (Aknin et al., 2013). The huge intensity of social crowdfunding media shows the antithetical of a traditional financial theory which assumes that all investors are homo economicus, who are always rational in making decisions (Hofmann et al., 2010).

In Indonesia, $90 \%$ of the population consider religion as an important aspect of their lives (Pew Research Center, 2015). The results of the Pew Research survey also indicate the significance of religion in people's lives in Indonesia. Therefore, the financial theory assumption which mentions that all men are rational may not be entirely correct. Some experts argue that it is too simple to assume that all investors are rational (Kahneman and Tversky, 1979). The assumption of rationality does not describe the phenomenon that occurs in the financial world accurately (Stanovich, 2011).

Yet, although the practices might have been excessive, the studies of social crowdfunding media are far from adequacy. Albeit there are, research on social crowdfunding mainly focused on the economic aspects and the influence of individual demographic profiles on social crowdfunding rather than the determinants of their intention (Glac, 2012). While in fact, consumer attitude and intention are the most decisive determinants of people's behavior (Vermeir and Verbeke, 2006). Irrational behavior that arises in the trying behavior of donating through social crowdfunding media can be determined by understanding the motivation which underlies this behavior. Theory of Trying (Bagozzi and Warshaw, 1990) is used in this study to explain the process of forming one's attitude and intention to try donating through social crowdfunding media.

Drawing from the background explained previously, the research questions thus as follow:

1. Does a student's attitude towards success have a positive effect on attitude towards trying to donate through social crowdfunding media?

2. Does a student's attitude towards failure have a positive effect on attitude towards trying to donate through social crowdfunding media?

3. Does a student's attitude towards the process have a positive effect on attitude towards trying to donate through social crowdfunding media?

4. Does a student's attitude towards trying has a positive effect on the intention to try donating through social crowdfunding media?
5. Do student's subjective norms have a positive effect on the intention to try donating through social crowdfunding media?

6. Does a student's past behavior have a positive effect on the intention to try donating through social crowdfunding media?

\section{LITERATURE REVIEW}

\subsection{Social Crowdfunding Media}

Crowdfunding is the practice of funding a project or venture by raising money from a large number of people who each contribute a relatively small amount, typically via the Internet (Crowdfunding, 2019). Therefore, social crowdfunding, which is an extension of the function of crowdfunding, is an open fundraising action aimed at anyone who is willing to donate money in order to help people or groups at a specified time period (Gerber et al., 2012). The concept of social crowdfunding is intended to accommodate people who want to donate in a small amount of money (Lambert and Schwienbacher, 2010).

In fact, collecting donations through social crowdfunding media has become a world trend. Data shows that a total of USD 2.85 million has been donated through this media (Massolution, 2015). The literature also stated that individual empathy and the perceived credibility of crowdfunding projects are the factors that influence the intention to donate through social crowdfunding media (Liu et al., 2018). Furthermore, the donating behavior through social crowdfunding media is also driven by performance expectations, expectations of effort, social influence, expectations of experience, and the level of trust ( $\mathrm{Li}$ et al., 2018).

An example of a social crowdfunding platform that helps people in raising funds for various social projects in Indonesia is Kitabisa (2019). As a social crowdfunding media, kitabisa.com has been able to survive in the industry of online social fundraising. Non-profit organizations and individuals can use this platform for social project campaigns. From 2013 to 2018, a total of 12,955 social campaigns have been funded (Kitabisa, 2019). While the total donations collected through Kitabisa.com has been reaching IDR $349,538,870,570$ from 877,880 people who participated in the donation.

\subsection{Theory of Trying}

The theory is aimed to elaborate on the process of people who strive to implement behavior in order to achieve a very difficult goal (Bagozzi and Kimmel, 1995). That is, when someone tries to pursue a goal, he pretends it as a tension that triggers motivation that only has the possibility of success because they have an interest in the outcome. Thus, they sacrifice anything to carry out the behavior, specifically, people open the possibility of two consequences, which are (1) have tried and succeeded, or (2) failed despite trying (Dharmmesta, 2000).

The theory of Trying divides attitude as three different dimensions. These dimensions are attitude towards success, attitude towards failure, and attitude towards the process. By 
dividing attitudes into these three dimensions, we will obtain a thorough understanding of people's motivation to do certain behavior. Thus, treating attitude as a one dimension concept will exclude the human's motivation sense on intention.

In the theory, the behavior that was supposed to be the final output in the Theory of Reasoned Action model (Fishbein and Ajzen, 1975) and Theory of Planned Behavior (Ajzen, 1991) is altered as an attempt to achieve goals (Solomon, 2013). The need for alteration is caused by the existence of disturbing factors that can influence the relationship between one's intention and behavior (Solomon, 2013). For example, an employee tries to wear a tie because he wants to impress himself as a professional before his boss. In fact, professional indicators according to their superiors are not only measured by the wear of a tie. The example shows that trying behavior is an effort carried out in order to achieve an intermediate goal in order to obtain the final goal, which is to impress the boss.

\subsection{Attitude towards Behavior}

Attitude is indeed the most influential factor of intention to behavior (Al-Rafee and Cronan, 2006). One's positive attitude towards an object does not necessarily manifest into a positive attitude towards a behavior. That is why it is necessary to differ attitude towards object and attitude towards the behavior. A person may love the brand of Mercedes-Benz car, however, due to some circumstances, such as the inability to pay, the unnecessary features of the car, or the unaffordable price may not translate into a positive attitude towards buying (behavior) a Mercedes-Benz car.

However, although many findings showing that attitude towards behavior has closer proximity to behavior than the attitude towards an object (e.g., (Dharmmesta, 2002); (Altaf et al., 2017); (Datta et al., 2018)) yet, on the other hand, some studies assume that attitude towards an object is a direct antecedent of intention or behavior (e.g., Lee et al. (2009); Hartmann and Apaolaza-Ibá nez (2012); Farías (2018)).

\subsection{Hypotheses Development}

Based on the background literature that is explained antecedently, six hypotheses were developed in this research.

The variable of attitude towards success was originally initiated from the Theory of Self-Regulation (Bandura, 1991). Attitude towards success variable is the implementation of one's anticipation in overcoming the future success consequences (Carver and Scheier, 1990). Basically, one will take anticipatory steps on the implications of success in trying something. When the resources to reach one's goal are limited and there is no certainty that the intermediate goal will produce success or failure, then the urge to succeed tend to increase.

Attitude towards success describes the degree of one's willingness to achieve success in completing goals (Bagozzi and Warshaw, 1990). The volition to success is manifested in the attitude towards success which will then have an influence on attitude towards trying (Bandura, 1991). The higher people's attitude towards the success of donating through the medium of social crowdfunding, the higher their attitude towards trying to donate through the medium of social crowdfunding. The same rule applies to the opposite state.

$H_{1}$ : Attitude towards success has a positive effect on attitude towards trying to donate through social crowdfunding media.

In line with the attitude towards success, one will take an anticipation step towards the consequences of failure in trying something. However, it should be a concern that someone who really wants to achieve an important goal will accept the consequences of trying either it is succeeding or failing (Dharmmesta, 2000). Thus, one's effort towards trying is not based on the result of trying itself but based on his attitude towards success and failure.

One's attitude towards failure varies depends on the level of one's self-efficacy (Bandura, 1991). When the level of selfefficacy is high, failure will not become an obstacle for someone to achieve a goal. The consideration of failing which is manifested in the form of attitude towards failure will then be assumed to have an effect on attitude towards trying. The stronger a person faces failure, the more positive his attitude towards trying to donate through the medium of social crowdfunding. But if the person if weak in the face of failure in completing the final goal, then the attitude towards trying to donate through the medium of social crowdfunding will weaken. .

$\mathrm{H}_{2}$ : Attitude towards failure has a positive effect on attitude towards trying to donate through social crowdfunding media.

The important factor for someone to conduct a trying behavior is the activity or process of the behavior itself (Bandura, 1991). A person will not devastate his time to undergo a process that is not perceived as useful (Bandura, 1991). Thus, he will reduce his efforts to activities that are deemed worthless. It implies that the process becomes a strong aspect in determining attitude towards trying to donate through the medium of social crowdfunding (Bagozzi and Warshaw, 1990).

$\mathrm{H}_{3}$ : Attitude towards the process has a positive effect on attitude towards trying to donate through social crowdfunding media.

Referring to the Eagly-Chaiken Composite Model (Eagly and Chaiken, 1993) which shows that attitude towards behavior has an impact on intention, then the attitude towards trying is assumed to have the same impact on intention since trying is also considered as behavior. Trying is a collection of behavior that is done in order to achieve the ultimate goal (Bagozzi and Warshaw, 1990). The attitude towards trying is the result of an evaluation of attitude towards success, attitude towards failure, and attitude towards process (Bagozzi and Warshaw, 1990). Several studies reported that attitude towards trying has a positive impact on intention to try (e.g., (Chaouali et al., 2017).

$\mathrm{H}_{4}$ : Attitude towards trying has a positive effect on the intention to try donating through social crowdfunding media.

According to Swee et al. (2001), social pressure can have an influence on an individual's intention to do a certain activity. The influence depends on one's vulnerability towards the pressure. In a social environment, a person may perceive that his surroundings expect him to behave in a way that is accepted by society (A. and M., 2008). This perception will further influence people to intend to try. In this study, one is considered to 
have a tendency to donate through the medium of social crowdfunding when the community suggests him to do so.

$\mathrm{H}_{5}$ : Subjective norm has a positive effect on the intention to try donating through social crowdfunding media.

Past behavior is generally defined as the action or reaction towards external and internal symptoms in the past (Sommer, 2011). When one's attitude toward trying is not certain, past behavior becomes a single predictor of intention to try. Even when his attitude towards behavior is certain, past behavior influences the intention to try as one's personal inferences rather than as one's reflection of past behavior (Bagozzi and Warshaw, 1990). Past behavior can also be used as a reference to predict the quality of a product provided by the company. Therefore, in this study, past behavior is considered as the determinant of intention to try donating through social crowdfunding media.

$H_{6}$ : Past behavior has a positive effect on the intention to try donating through social crowdfunding media.

\section{RESEARCH METHOD}

In this research, the data was collected through two stages. The first stage adopted the qualitative method and the second one administered using a quantitative method. In the first stage, a presentational sample was used to represent the target population. The collection of this sample is aimed to identify salient beliefs that are associated with attitudes objects or certain (Fishbein and Middlestadt, 1995). A content analysis was thus administered to provide common and accurate best practices in scale development for the survey in the next stage.

To obtain people's salient modal beliefs about trying to donate through the medium of social crowdfunding, an interview was conducted among 30 informants. The requirements of the informant in this study are as follow, they should be the one who: (1) have been donating for at least once in a year (Bagozzi and Warshaw, 1990) and (2) their minimum age is 18 years old (Bradburn and Wansink, 2004). In this study, the respondents were students with a minimum age of $18-27$.

The first step when using content analysis is selecting the unit of analysis (e.g., a person, an organization, a book). After determining the unit of analysis, which is a person, a meaning unit, that is the sequence of words that relate to the same central meaning (Baxter, 1991) was gathered. Subsequently, the condensation process, as it refers to a process of shortening while still preserving the core (Graneheim and Lundman, 2004) was conducted.

Table 1 shows the examples of meaning unit, condensed unit, and code-based from the transcript obtained in the interview. Attributes that are mentioned most frequently by the informants are then used as the fundamental measures in the second stage.

To test the research hypotheses, a quantitative method was used. A survey through questionnaires, as the second stage of this research, was distributed to measure people's intention of trying to donate through the media of social crowdfunding media. The survey method was considered more appropriate to measure consumer attitudes toward behavior or objects (Aaker et al., 2013). Data collection was conducted offline. A sample of 300 respondents who have never tried the donation through social crowdfunding media was drawn. A 5-point semantic differential scale was used in this study.

To assure that the measurements used in this study are valid, two validity tests which consist of convergence and discriminant test were examined. This validation test is called the measurement model examination. Afterward, the structural model examination is administered using Structural Equation Modeling (SEM) method. It was used to evaluate the structural or path model, which examine a series of dependence relationships simultaneously (Hair et al., 2014). By using SEM, the relationship between the constructs can be obtained simultaneously. SEM is precisely used because it is a confirmation technique (Tabachnick and Fidell, 2001) which is based on a theory (Cheng, 2001).

(i) Sample characteristics

Respondent characteristics are presented in Table 2.

(ii) Measurement

In constructing the questionnaire items, we tried to adhere to the language and terms used by previous researchers for variables developed by them. The specific operational definitions are as follows.

Past Frequency (F). The past frequency of trying administers a one-year time frame and was assessed by a semantic differential 5-point scale of the form, "Within the last one year, I have been donating through any media other than online social crowdfunding media" The answer component would be very rare/very often.

Recency (R). The frequency of trying in the past three months was the measure. We obtained the number of three months from the interview conducted by asking an in-depth question to the donators. Using a semantic differential 5-point scale, the statement would be as follow, "Within the last three months, I have been donating through any media other than online social crowdfunding media" The answer component would be very rare/very often.

Intention to Try (IT). The intention was measured by using one statement item adopted from Bagozzi and Warshaw (1990) study. While the answer components were gathered from the transcript obtained from the interview which was conducted previously. Using semantic differential five-point scales, the following statement is used to measure intention construct, "I ... to try to donate through the medium of social crowdfunding" The answer component would be doing not tend/tend, do not want/want, do not plan/plan.

Subjective Norms toward Trying (SNt). This construct was measured with these following items: (a) "Most people who are important to me think/do not think that I should try to donate through the medium of social crowdfunding" (b) "Most people who are important to me suggest/do not suggest that I should try to donate through 


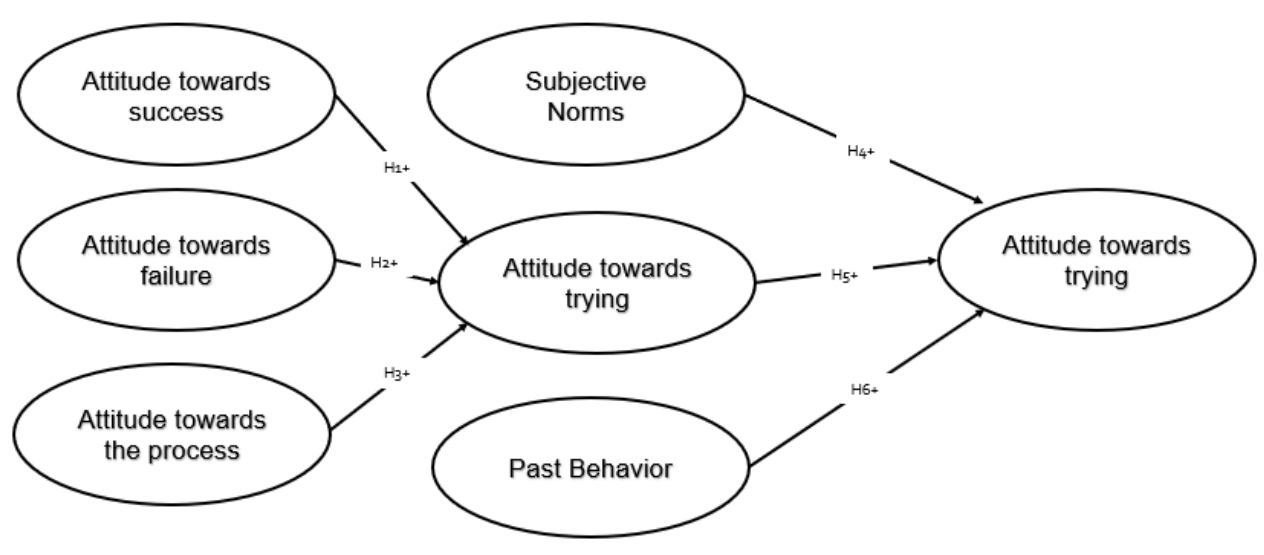

Figure 1: The Research Model

Table 1: Examples of the meaning unit, condensing unit, and code

\begin{tabular}{lll}
\hline Meaning unit & Condensed unit & Code \\
\hline $\begin{array}{l}\text { The process of the trial should be en- } \\
\text { joyable, of course. None of us wants } \\
\text { complicated procedures, so with all } \\
\text { of this technology advances, donating } \\
\text { should be just one click away. }\end{array}$ & & \\
$\begin{array}{l}\text { In this very busy world, we often don't } \\
\text { have time to visit an orphanage house. }\end{array}$ & The need to save time & Time efficiency \\
$\begin{array}{l}\text { Thus, we need a platform that can ac- } \\
\text { commodate us. }\end{array}$ & \\
$\begin{array}{l}\text { If the money is misused, I would be } \\
\text { very sad. }\end{array}$ & Very sad & Devastated \\
$\begin{array}{l}\text { I guess I will try to help people in need } \\
\text { through social crowdfunding media. }\end{array}$ & Willingness to try & $\begin{array}{l}\text { Tendency to do- } \\
\text { Source Trande }\end{array}$ \\
\hline
\end{tabular}

Source: Transcript of the interview.

Table 2: Respondent Profile

\begin{tabular}{llcl}
\hline Variable & Category & Frequency (n) & Percentage \\
\hline \multirow{2}{*}{ Gender } & Male & 138 & $46,00 \%$ \\
& Female & 162 & $54,00 \%$ \\
\hline \multirow{4}{*}{ Monthly expenditure } & $0-1.000 .000$ & 155 & $51,67 \%$ \\
& $1.000 .001-2.500 .000$ & 47 & $15,67 \%$ \\
& $2.500 .001-5.000 .000$ & 80 & $26,67 \%$ \\
& $5.000 .001-10.000 .000$ & 18 & $6,00 \%$ \\
\hline
\end{tabular}

Table 3: The goodness of Fit Index

\begin{tabular}{ccccc}
\hline Type goodness of fit model & $\begin{array}{l}\text { Goodness of } \\
\text { fit model in- } \\
\text { dex }\end{array}$ & $\begin{array}{l}\text { Recommended } \\
\text { value }\end{array}$ & Result & Notes \\
\hline Absolute fit measures & GFI & $\geq 0.900$ & 0.916 & Good \\
Absolute fit measures & RMSEA & $\leq 0.080$ & 0.058 & Good \\
Incremental fit measures & CFI & $>0.954$ & 0.941 & Moderate \\
Parsimonious fit measures & AGFI & $>0.900$ & 0.904 & Good \\
\hline
\end{tabular}

Source: Hair et al. (2014, pg. 577-581). 


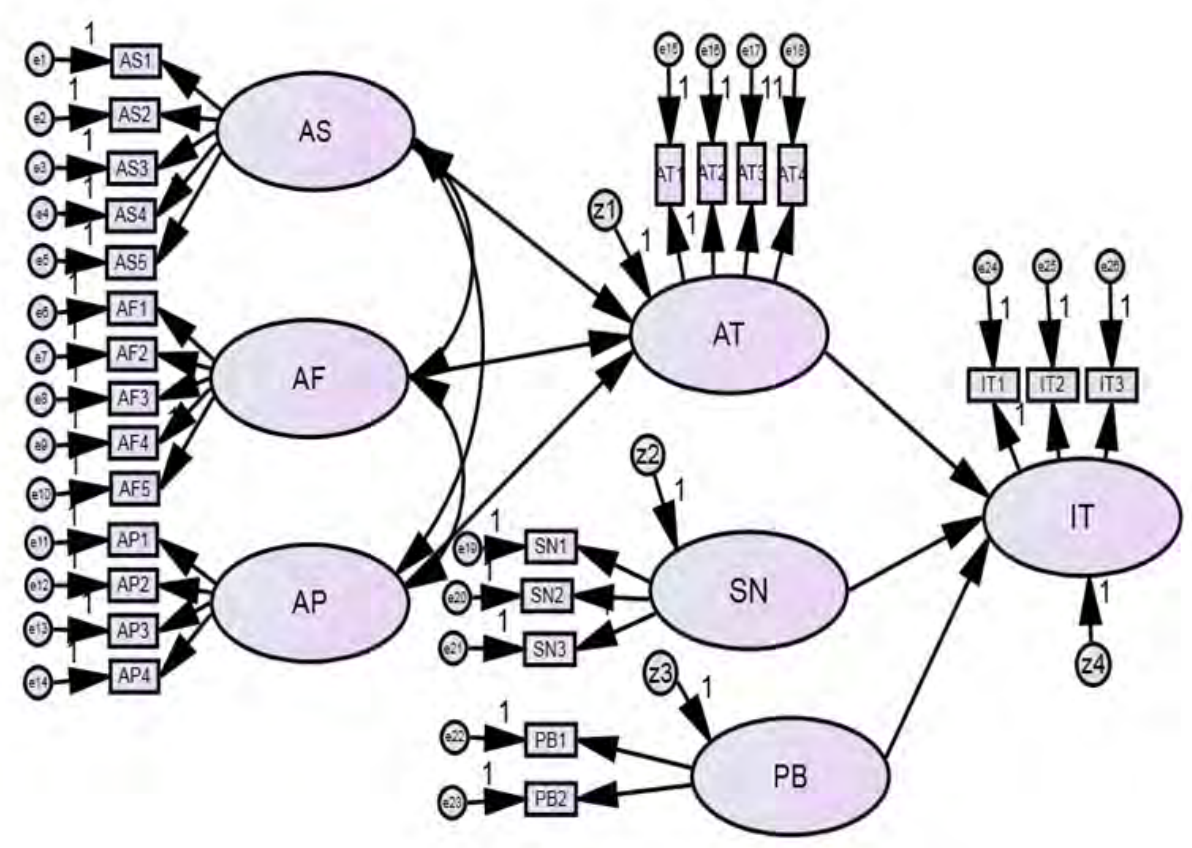

Figure 2: Structural Equation Modeling

the medium of social crowdfunding" (c) "Where people who are important to me try to donate through the medium of social crowdfunding, then I would probably follow/would probably not follow" five-point scales had been used in these statements.

Attitude toward Trying (At). Attitude towards trying was measured with this following item: "All things considered, my trying to donate through the medium of online social crowdfunding would make me feel ...". The five-point scales of the following answer components are: very benefited/very not benefited, very happy/very unhappy, very wise/very unwise, and very comfortable/very uncomfortable.

Attitude toward Trying and Succeeding (As). Respondents indicated how satisfied/disappointed, happy/unhappy, spiritful/ flagging, confident/unconfident, wise/unwise, benefited/not benefited, and relieved/distraught. The statement would be "My trying and succeeding at achieving what I want during the trial donating through the medium of social crowdfunding would make me feel ... ". The five-point scales had been used in this statement.

Attitude toward Trying but Failing (Af). Respondents indicated how satisfied/disappointed, happy/unhappy, spiritful/ flagging, confident/ unconfident, wise/unwise, benefited/not benefited, and relieved/distraught. The statement would be "My trying but failing achieving what I want during the trial of donating through the medium of social crowdfunding would make me feel ..." ". The fivepoint scales had been used in this statement.

Attitude toward Process (Ap). By five-point semantic differential scale such as comfortable/not comfortable, pleasant/ unpleasant, enjoyable/not enjoyable, respondents indicated how "My trying to try donating through the medium of social crowdfunding, ignoring whether or not I actually succeed at achieving what I want, would make me feel ...". The answer components are obtained from in-depth questions of the interview conducted in the previous stage.

\section{RESULT}

The model evaluation in this study was carried out by evaluating the measurement and structural model (Chin, 2008). The evaluation of model measurement is purposed to assess the validity and reliability of the measurement items. While the Structural Equation Modeling (SEM) method was applied to analyze the structural model.

Table 3 shows the result of the Goodness of Fit of the model proposed in this study. The result of the fit indices suggested by Hair et al. (2014) are as follow. Comparative Fit Index (CFI) larger than 0.90 indicates a good fit, Goodness of Fit Index (GFI) larger than 0.90 indicates a good fit, Adjusted Goodness of Fit Index (AGFI) larger than 0.90 indicates a good fit, and Root Mean Square Error of Approximation (RMSEA) between 0.05 and 0.08 indicate a good fit. From the Goodness of Fit model testing administered in this study, it was obtained the results as follow: $\mathrm{GFI}=0.916$; $\mathrm{RMSEA}=0.058$; $\mathrm{CFI}=0.941$; AGFI $=0.904$.

Path coefficient analysis in SEM is intended to test the hypothesis proposed in this study. The hypothesis is accepted when the level of significance of the relationship between variables on the regression weight in the maximum likelihood estimate has a p-value $<0.05$ (Cooper and Schindler, 2014). In 
addition, hypothesis testing was done by looking at critical ratio $(\mathrm{CR})$ with a value of \pm 1.96 at the significance level $\mathrm{p}=0.05$ and \pm 2.58 at the level of significance $\mathrm{p}<0.01$.

The hypothesis is supported if the influence of a construct on other constructs produces estimated parameter values in the form of a critical ratio (CR) greater than \pm 1.96 at the 0.05 significance level. The hypothesis testing is done by looking at the $\mathrm{CR}$ showed in regression weight output. In other words, a construct has a significant influence on other constructs when the $\mathrm{CR}$ is greater than \pm 1.96 . Whereas the value estimation of standardized regression weight output is used to show the direction and the level of significance between the variables.

Figure 2 displays the structural model aimed to examine the hypotheses proposed in this study. As stated previously, the effect of attitude towards success, attitude towards failure and attitude towards process on attitude towards trying to donate through social crowdfunding media were tested in this model. Furthermore, the effect of attitude towards trying, subjective norms, and past behavior on an intention to try donating through social crowdfunding media were also tested in this model. All of those relationships in the model were tested simultaneously.

Table 4: Hypotheses Testing

\begin{tabular}{cll}
\hline Hypotheses & $\begin{array}{l}\text { Critical } \\
\text { Ratio }\end{array}$ & Decision \\
\hline$H_{1}$ & 2,692 & Supported \\
$H_{2}$ & 4,064 & Supported \\
$H_{3}$ & 4,687 & Supported \\
$H_{4}$ & 4,319 & Supported \\
$H_{5}$ & 4,870 & Supported \\
$H_{6}$ & 2,398 & Supported \\
\hline
\end{tabular}

Table 4 describes that all of the hypotheses in this study are supported based on the data collected. The hypotheses testing in this study refers to the value generated and estimated using the SEM method. Evidence showed that all hypotheses are accepted with a significant value greater than 1.96 .

\section{CONCLUSION}

This study aims to determine the extent of student's courage to try donating through the medium of social crowdfunding. The basic reason to conduct this research is that student's altruistic behavior is considered high, but there is only a little research focusing on donating through the new medium, which is online social crowdfunding. The Theory of Trying was used to explain in detail the determinants of student's intention to donate, and furthermore, by using the theory, we can also measure the underlying motivation of their intention. The results of this study indicated that all hypotheses were accepted. Thus, it is proven that this under-researched Theory of Trying is powerful to explain the antecedents of people who intend to do certain behavior.

\section{References}

A., S.-M., M., F., 2008. Predictors of intentions to perform six cancer-related behaviors: roles for injunctive and descriptive norms. Psychol Health Med 13 (4), 389-401.

Aaker, D. A., Kumar, V., Leone, R. P., Day, G. S., 2013. Marketing Research, 11 th ed. John Wiley Sons, Singapore.

Ajzen, I., 1991. The theory of planned behavior. Organizational Behavior and Human Decision Process 50 (2), 179-211.

Aknin, L. B., Barrington-Leigh, C. P., Dunn, E. W., Helliwell, J. F., Burns, J., Biswas-Diener, R., Kemeza, I., Nyende, P., Ashton-James, C. E., 2013. Prosocial spending and well-being: Cross-cultural evidence for a psychological universal. Journal of Personality and Social Psychology 104 (4), 635652.

Al-Rafee, S., Cronan, T. P., 2006. Digital piracy: Factors that influence attitude toward behavior. Journal of Business Ethics 63, 237-259.

Altaf, S. N., Perumal, S., Hussin, Z., 2017. Consumption values and consumer attitude towards automobile purchase. Paradigms 11 (1), 1-5.

Bagozzi, R. P., Kimmel, S. K., 1995. A comparison of leading theories for the prediction of goal-directed behaviors. British Journal of Social Psychology 34, 437-461.

Bagozzi, R. P., Warshaw, P. R., 1990. Trying to consume. Journal of Consumer Research 17, 127-140.

Bandura, A., 1991. Social cognitive theory of self-regulation. Organizational Behavior and Human Decision Processes 50 (2), 248-287. URL: https : //doi . org/10.1016/0749-5978(91)90022-L

Baxter, L., 1991. Content analysis. In studying interpersonal interaction (Montgomery, B.M. and duck, S., Eds.). Guilford Press.

Bernardino, S., Santos, J. F., Ribeiro, J. C., 2016. Social crowdfunding: A new model for financing regional development? Journal of Urban and Regional Analysis 8 (2), 97-115.

Bradburn, N.and Sudman, S., Wansink, B., 2004. Asking Questions - the Definitive Guide to Questionnaire Design - for Market Research, Political Polls, and Social and Health Questionnaires. Jossey-Bass.

Buragohain, P., Sonowal, M., 2016. Teaching helping attitude among adolescent students. International Journal of Humanities Social Sciences and Education 3 (11), 17-24.

Carver, C. S., Scheier, M. F., 1990. Origins and functions of positive and negative affect: A control-process view. Psychological Review 97 (1), 19-35. URL: https : //doi .org/10.1037/0033-295X.97.1.19 DOI: $10.1037 / 0033-295 X .97 .1 .19$

Chaouali, W., Souiden, N., Ladhari, R., 2017. Explaining adoption of mobile banking with the theory of trying, general self-confidence, and cynicism. Journal of Retailing and Consumer Services 35, 57-67.

Cheng, E. W. L., 2001. Sem being more effective than multiple regression in parsimonious model testing for management development research. Journal of Management Development 20 (7), 650-667.

Chin, W. W., 2008. Structural equation modeling in marketing: Some practical reminders. Journal of Marketing Theory and Practice 16 (4), 287-298.

Cooper, D. R., Schindler, P. S., 2014. Business Research Methods. McGrawHill.

Cosgrave, J., 2007. Tsunami Evaluation Coalition, Synthesis Report: Expanded Summary, Joint Evaluation of the International Response to the Indian Ocean Tsunami. TEC - Tsunami Evaluation Coalition, available at.

URL: http : //www . alnap.org/resource/5536

Coulter, I. D., Wilkes, M., Der-Martirosian, C., 2007. Altruism revisited: A comparison of medical, law and business student's altruistic attitudes. Medical Education 41 (4), 341-345.

Crowdfunding, 2019. Oxford online dictionary. URL: https ://www.lexico.com/definition/crowdfunding

Datta, B., Sajnani, M., Thomas, J., 2018. Travellers attitude towards online purchase of travel products: An empirical study of online travel portals. Geo Journal of Tourism and Geosites 21 (1), 133-142.

Dharmmesta, B. S., 2000. Perilaku mencoba beli: Sebuah kajian analitis model bagozzi-warshaw untuk panduan peneliti. Jurnal Ekonomi dan Bisnis Indonesia 15 (4), 453-470.

Dharmmesta, B. S., 2002. Trying to act: An empirical study of investigating higher education consumers. Gadjah Mada International Journal of Business 4 (1), 45-66.

Eagly, A., Chaiken, S., 1993. The Psychology of Attitudes. Harcourt.

Farías, P., 2018. The effect of advergames, banners and user type on the atti- 
tude to brand and intention to purchase. Revista Brasileira De Gestāo De Negócios 20 (2), 194-209.

Fintech Singapore, 2019. Top 11 Donation and Reward-Based Crowdfunding Platforms in Asia — Fintech Singapore.

URL: https://fintechnews.sg/10112/crowdfunding/ top-donation-reward-based-crowdfunding-platforms-asia/

Fishbein, M., Ajzen, I., 1975. Belief, Attitude, Intention and Behavior: An Introduction to Theory and Research. Addison-Wesle, Reading, Massachusetts.

Fishbein, M., Middlestadt, S., 1995. Noncognitive effects on attitude formation and change: Fact or artifact? Journal of Consumer Psychology 4 (2), 181202.

Gerber, E., Hui, J., Kuo, P.-Y. P., 02 2012. Crowdfunding: Why people are motivated to post and fund projects on crowdfunding platforms. Vol. 10.

Glac, K., 2012. The impact and source of mental frames in socially responsible investing. Journal of Behavioral Finance 13 (3), 184-198.

Graneheim, U., Lundman, B., 2004. Qualitative content analysis in nursing research: concepts, procedures and measures to achieve trustworthiness. Nurse Educ Today 24 (2), 105-112.

URL: https://doi.org/doi:10.1016/j.nedt.2003.10.001 DOI: doi : $10.1016 / j$.nedt.2003.10.001

Guo, Q., Feng, L., Wang, M., 2017. Chinese undergraduate's preferences for altruistic traits in mate selection and personal advertisement: Evidence from q-sort technique. International Journal of Psychology 52 (2), 145-153.

Hair, J. F., Black, W. C., Babin, B. J., Anderson, R. E., 2014. Multivariate Data Analysis, 7th ed. Prentice-Hall Inc, Upper Saddle River, New Jersey.

Hartmann, P., Apaolaza-Ibá nez, V., 2012. Consumer attitude and purchase intention toward green energy brands: The roles of psychological benefits and environmental concern. Journal of Business Research 65 (9), 1254-1263.

Hofmann, W., De Houwer, J., Perugini, M., Baeyens, F., Crombez, G., 2010. Evaluative conditioning in humans: A meta-analysis. Psychological Bulletin 136 (3), 390-421.

Indonesia Investments, 2019. Infrastruktur di Indonesia - Analisis Prasarana \& Ekonomi - Indonesia Investments.

URL: https://www.indonesia-investments.com/id/bisnis/ risiko/infrastruktur/item381

Kahneman, D., Tversky, A., 1979. Prospect theory: An analysis of decision under risk. Econometrica 47 (2), 263-291.

Kitabisa, 2019. Kitabisa.com - Indonesia's Fundraising Platform. URL: https : //kitabisa.com/about-us

Lambert, T., Schwienbacher, A., 2010. An empirical analysis of crowdfunding. Social Science Research Network 1578175, 1-23.

Lee, H., Park, T., Moon, H. K., Yang, Y., Kim, C., 2009. Corporate philanthropy, attitude towards corporations, and purchase intentions: A south korea study. Journal of Business Research 62 (10), 939-946.

Li, Y., He, T., Song, Y., Yang, Z., Zhou, R., 2018. Factors impacting donors' intention to donate to charitable crowd-funding projects in china: A utaut- based model. Information, Communication Society 21 (3), 404-415.

Liu, L., Suh, A., Wagner, C., 2018. Empathy or perceived credibility? An Empirical Study on Individual Donation Behavior in Charitable Crowdfunding. Internet Research 28 (3), 623-651.

Massolution, 2015. R2015CF Crowdfunding Industry Report. URL: http://reports.crowdsourcing.org/index.php?route= product/product\&product_id=54

Nuswantoro, H., 2019. Can we improve the quality of Indonesian public service? - Opinion - The Jakarta Post.

URL: https://www.thejakartapost.com/academia/2018/10/29/ can-we-improve-the-quality-of-indonesian-public-service. html

Pew Research Center, 2015. Religious Composition by Country, 2010-2050 — Pew Research Center.

URL: https : //www.pewforum.org/2015/04/02/ religious-projection-table/

Sara, A., Elena, Z., Valentina, S., Marta, E., Dania, C., Giancarlo, C., Pozzi, M., 2018. Knowledge, motivations and barriers regarding blood donation among students in different undergraduate majors. American Journal of Applied Sciences 15 (9), 432-442.

Simorangkir, E., 2018. 9 Juta Anak RI Alami Stunting.

URL: https://finance.detik.com/berita-ekonomi-bisnis/ d-4218667/9-juta-anak-ri-alami-stunting

Solomon, M. R., 2013. Consumer Behavior: Buying, Having, and Being, 10th ed. Pearson Education Limited, Essex.

Sommer, L., 2011. The theory of planned behaviour and the impact of past behaviour. International Business Economics Research Journal (IBER) 10 (1). URL: https ://doi.org/10.19030/iber.v10i1.930

Stanovich, K., 2011. Rationality and the Reflective Mind. Oxford University Press.

Swee, H. A., Peng, S. C., A.C., L. E., Siok, K. T., 06 2001. Spot the difference: Consumer responses towards counterfeits. Journal of Consumer Marketing 18 (3), 219-235.

URL: https : //doi.org/10.1108/07363760110392967

DOI: $10.1108 / 07363760110392967$

Tabachnick, B. G., Fidell, L. S., 2001. Using Multivariate Statistics, 4th ed. Pearson Education Company, MA.

Vermeir, I., Verbeke, W., 2006. Sustainable food consumption: Exploring the consumer attitude-behavioral intention gap. Journal of Agricultural and Environmental Ethics 19 (2), 169-194.

World Bank, 2019. Indonesia - Data.

URL: https ://data. worldbank .org/country/indonesia

World Education News +Reviews, 2019. Education in Indonesia. Accessed: 2019-11-26.

URL:

https://wenr.wes.org/2019/03/ 